\title{
DAMPAK INDUSTRIALISASI PEDESAAN TERHADAP KESEJAHTERAAN MASYARAKAT DI DESA CIHERANG PONDOK, KECAMATAN CARINGIN, KABUPATEN BOGOR
}

\section{(The Impact of Rural Industrialization towards Community Welfare)}

\author{
Thessa Ayuningtias ${ }^{1)}$ dan Murdianto ${ }^{1)}$ \\ ${ }^{1)}$ Departemen Sains Komunikasi dan Pengembangan Masyarakat, Fakultas Ekologi Manusia, Institut \\ Pertanian Bogor, Darmaga Bogor 16680, Indonesia \\ E-mail: ayuningtiasthessa@gmail.com; murdianto@apps.ipb.ac.id
}

\begin{abstract}
Rural industrialization is a development step to push the economic growth. Implementation of rural industrialization program not focused in the city but in rural area with purpose so that the development could disseminate evenly until the grassroots level. There was a shifting of livelihood caused by industrial penetration in rural area, from agriculture to non agriculture. Meanwhile from an economic view, the presence of industry could open an employment and business opportunity for the people around there. The aim of this research is to analyze the correlation of the impact of rural industrialization with community welfare between them who have livelihood in industrial and non industrial sectors. This research is using quantitative approach with survey method and supported by qualitative data. The result of this study shows that there are different correlations in the impact of rural industrialization with community welfare between them who have livelihood in industrial and non industrial sectors.
\end{abstract}

Keywords: livelihood, agriculture, non agriculture

\begin{abstract}
ABSTRAK
Industrialiasasi pedesaan merupakan suatu langkah pembangunan untuk mendorong pertumbuhan ekonomi. Kegiatan industri ini tidak dipusatkan di perkotaan, melainkan mendorong pertumbuhan ekonomi di tingkat pedesaan dengan tujuan agar pembangunan tersebar secara merata hingga ke lapisan akar rumput. Hadirnya industri di pedesaan, jika dilihat dari aspek sosial telah menggeser kehidupan pertanian. Sedangkan dari aspek ekonomi, berdirinya suatu industri di pedesaan dapat membuka kesempatan bekerja dan kesempatan berusaha bagi warga sekitar. Tujuan dari penelitian ini adalah untuk menganalisis hubungan dampak industrialisasi pedesaan dengan kesejahteraan masyarakat antar kelompok dengan pola nafkah industri dan non industri. Penelitian ini menggunakan pendekatan kuantitatif dengan metode survei dan didukung oleh data kualitatif. Hasil penelitian ini menunjukkan bahwa terdapat perbedaan hubungan dampak industrialisasi pedesaan dengan kesejahteraan masyarakat antara kelompok dengan pola nafkah industri dan non industri.
\end{abstract}

Kata kunci: nafkah, pertanian, non pertanian 


\section{PENDAHULUAN}

Secara umum, prospek pembangunan sebuah negara mengarah kepada hal perbaikan dan perkembangan dari kondisi sebelumnya. Jika ditinjau lebih spesifik, pembangunan khususnya dalam sektor ekonomi bertujuan untuk mencapai sebuah tingkat dimana masyarakat dinilai sejahtera. Seperti yang dipaparkan oleh Gandi (2011), Indonesia yang dikenal dengan negara agraris berusaha untuk meningkatkan laju pertumbuhan di sektor industri dalam beberapa puluh tahun terakhir karena sektor ini dianggap mampu memacu perekonomian negara. Hal tersebut didukung dengan data dari BPS (2016) yang menunjukkan bahwa di Jawa Barat, jumlah masyarakat yang bekerja pada sektor industri terus meningkat setiap tahunnya sementara pada sektor pertanian terus mengalami penurunan. Hal tersebut mengindikasikan bahwa sektor pertanian saat ini kurang mampu menyerap tenaga kerja. Sedangkan sektor non pertanian khususnya industri dilansir mampu membuka peluang kerja yang besar bagi masyarakat.

Tabel 1 Perbandingan jumlah penduduk berumur 15 tahun ke atas serta lapangan pekerjaan utama pada sektor pertanian dan industri

\begin{tabular}{cccccc}
\hline \multirow{2}{*}{ No } & \multirow{2}{*}{ Sektor } & \multicolumn{4}{c}{$\begin{array}{c}\text { Jumlah Penduduk Berumur 15 } \\
\text { Tahun ke Atas (juta jiwa) }\end{array}$} \\
\cline { 3 - 6 } & & $\mathbf{1 9 8 5}$ & $\mathbf{1 9 9 5}$ & $\mathbf{2 0 0 5}$ & $\mathbf{2 0 1 5}$ \\
\hline 1 & Pertanian & 5,05 & 4,60 & 3,95 & 3,54 \\
2 & Industri & 0,95 & 2,53 & 2,74 & 3,98 \\
\hline
\end{tabular}

Sumber: Badan Pusat Statistik (2016)

Landasan penting Undang-undang Nomor 3 Tahun 2014 tentang Perindustrian menyatakan bahwa perindustrian diselenggarakan dengan tujuan: a) mewujudkan industri nasional sebagai pilar dan penggerak perekonomian nasional; $b$ ) mewujudkan kedalaman dan kekuatan struktur industri; c) mewujudkan industri yang mandiri, berdaya saing, dan maju, serta Industri Hijau; d) mewujudkan kepastian berusaha, persaingan yang sehat, serta mencegah pemusatan atau penguasaan industri oleh satu kelompok atau perseorangan yang merugikan masyarakat; e) membuka kesempatan berusaha dan perluasan kesempatan kerja; f) mewujudkan pemerataan pembangunan industri ke seluruh wilayah Indonesia guna memperkuat ketahanan nasional; dan g) meningkatkan kemakmuran dan kesejahteraan masyarakat secara berkeadilan.
Berkaitan dengan kebijakan tersebut, untuk mewujudkan pemerataan pembangunan nasional maka kegiatan perindustrian dipenetrasikan ke daerah pedesaan. Pertumbuhan angkatan kerja yang relatif tinggi di pedesaan dengan keterbatasan penyerapan tenaga kerja di sektor pertanian tanaman pangan, menempatkan peranan industri sebagai alat pembangunan pedesaan. Industrialisasi pedesaan merupakan suatu pembangunan dimana desa didorong untuk bertransformasi menjadi penyangga perekonomian bangsa. Kehadiran industri menyebabkan perubahan-perubahan di dalam bidang sosial-ekonomi seperti perubahan pemilikan dan pemanfaatan lahan, perubahan profesi dan perubahan pendapatan penduduk (Wijaya 2001).

Sayangnya, pembangunan nasional seperti yang diharapkan Indonesia terbilang belum merata. Masih adanya perbedaan tingkat kesejahteraan antara wilayah perkotaan dan pedesaan. Ketidaksejahteraan khususnya yang terjadi di pedesaan dapat dilihat dari angka kemiskinan. Badan Pusat Statistik (BPS) mencatat bahwa di Indonesia angka kemiskinan di pedesaan lebih besar dibandingkan dengan di perkotaan. Menurut data yang dikeluarkan Januari 2016, terhitung hingga September 2015 jumlah kemiskinan di perkotaan tercatat sebesar 10.61 juta jiwa sedangkan di pedesaan sebesar 17.89 juta jiwa (BPS 2016).

Menurut Purwanto (2003), hal ini dikarenakan alasan sebenarnya pembangunan industri di pedesaan adalah menekan biaya produksi karena upah buruh masyarakat desa yang relatif lebih rendah dibandingkan dengan masyarakat perkotaan. Selain itu, sistem kontrak yang diterapkan oleh sebagian besar industri semakin memperlemah posisi tawar masyarakat desa. Hal tersebut dapat dikarenakan pola pengembangan industri besar yang padat modal dengan prinsip efisiensi diterapkan melalui penggunaan alat modern sehingga membatasi penggunaan tenaga kerja berdasarkan keahlian tertentu, yang pada gilirannya menyebabkan tersingkirnya sejumlah masyarakat dari sektor tradisional.

Menurut Kecamatan Caringin dalam Angka (BPS 2013), Desa Ciherang Pondok merupakan desa dengan jumlah industri terbanyak yaitu 7 dari total 26 industri yang berada di Kecamatan 
Caringin atau sebesar 26,9 persen. Industri yang berada di desa tersebut berskala sedang dan besar. Industri-industri tersebut telah hadir sejak tahun 2003 dan hampir setiap tahunnya mengalami pertambahan jumlah. Hal ini tentu membawa berbagai perubahan sosial ekonomi bagi masyarakat sekitar. Berdasarkan uraian tersebut perlu dilakukan penelitian yang bermaksud untuk menganalisis hubungan antara dampak industrialisasi pedesaan dengan tingkat kesejahteraan masyarakat.

Latarbelakang tersebut kemudian memunculkan pertanyaan penelitian yaitu bagaimana hubungan dampak industrialisasi pedesaan dengan tingkat kesejahteraan masyarakat?

Tujuan dari penelitian ini adalah:

1. Menganalisis hubungan peluang kerja/usaha dengan tingkat pendapatan.

2. Menganalisis hubungan peluang kerja/usaha dengan akses terhadap pendidikan.

3. Menganalisis hubungan peluang kerja/usaha dengan akses terhadap kesehatan.

4. Menganalisis hubungan peluang kerja/usaha dengan kondisi tempat tinggal serta fasilitas yang dimiliki.

5. Menganalisis hubungan jual-beli lahan dengan tingkat pendapatan.

6. Menganalisis hubungan jual-beli lahan dengan akses terhadap pendidikan.

7. Menganalisis hubungan jual-beli lahan dengan akses terhadap kesehatan.

8. Menganalisis hubungan jual-beli lahan dengan kondisi tempat tinggal serta fasilitas yang dimiliki.

\section{PENDEKATAN TEORITIS}

\section{Industrialisasi}

Industrialisasi pada dasarnya merupakan suatu proses kerja yang didasarkan pada pemanfaatan teknologi untuk mendapatkan hasil secara efisien. Sebagai salah satu strategi modernisasi, industrialisasi dapat digunakan sebagai pemicu perubahan sosial. Melalui industrialisasi peranan teknologi menjadi semakin penting untuk diterapkan dalam proses produksi. Pada saat teknologi dimanfaatkan untuk melakukan produksi massal, maka industrialisasi menjadi faktor penggerak utama (prime mover) terjadinya perubahan sosial (Ponsioen dalam Purwanto 2003).

\section{Industrialisasi Pedesaan}

Menurut Tambunan dan Djaimi (2010), program industrialisasi pedesaan merupakan usaha untuk memajukan masyarakat yang masih agraris ke arah masyarakat industrial. Industrialisasi pedesaan bertujuan antara lain mendorong pertumbuhan pedesaan dengan mendiversifikasi sumber pendapatan, meningkatkan kesempatan kerja baru, meningkatkan produktivitas tenaga kerja dan usaha, mendekatkan hubungan fungsional sektor pertanian dan sektor usaha, mengendalikan urbanisasi dan mengurangi kemiskinan di pedesaan.

\section{Dampak Industrialisasi Pedesaan}

Purwanto (2003) dalam penelitiannya menyebutkan bahwa pembangunan industri di pedesaan akan membawa dampak seperti: 1) menyempitnya lahan akibat alih fungsi lahan; 2) arus migrasi masuk; 3) kepadatan penduduk; serta 4) terbukanya peluang kerja dan berusaha di sektor non pertanian.

Alih fungsi lahan adalah perubahan pemanfaatan lahan dari aktifitas yang bertujuan untuk produksi pertanian kepada aktifitas di luar sektor pertanian. Penurunan luas pemilikan tanah terjadi melalui proses jual-beli karena alih fungsi lahan pertanian untuk pembangunan industri maupun perluasan pemukiman. Migrasi adalah proses perpindahan penduduk secara geografis, spasial atau teritorial yang melibatkan perubahan tempat tinggal baik permanen maupun semi permanen. Peluang kerja/usaha adalah berbagai lapangan pekerjaan dan status pekerjaan yang tersedia dan memungkinkan seseorang untuk memperoleh pendapatan (Purwanto 2003).

\section{Kesejahteraan}

Undang-Undang tentang Kesejahteraan Sosial tahun 2008 pasal 1 ayat 1 menjelaskan bahwa, "Kesejahteraan sosial adalah kondisi terpenuhinya kebutuhan material, spiritual, dan sosial warga negara agar dapat hidup layak dan mampu mengembangkan diri, sehingga dapat melaksanakan fungsi sosialnya" (Rahayu 2014).

Menurut Badan Pusat Statistik (2015) untuk melihat tingkat kesejahteraan masyarakat suatu 
wilayah ada beberapa indikator yang dijadikan ukuran, antara lain adalah:

1) tingkat pendapatan; yaitu imbalan yang diterima oleh pekerja atas jasa yang diberikan dalam proses memproduksi barang dan jasa dalam suatu instansi/perusahaan.

2) akses terhadap pendidikan; yaitu pada tingkat apa seseorang mampu menamatkan pendidikan formal

3) akses terhadap kesehatan; yaitu kemampuan dalam memilih fasilitas kesehatan dan sumber biaya yang digunakan.

4) kondisi perumahan serta fasilitas yang dimiliki dalam rumah tangga; yaitu status kepemilikan, kualitas, dan fasilitas yang dimiliki pada tempat tinggal.

\section{Kerangka Pemikiran}

Industrialisasi di pedesaan tentunya sangat diharapkan pertumbuhannya oleh sebagian masyarakat pedesaan. Menurut Tambunan dan Djaimi (2010), program industrialisasi pedesaan merupakan usaha untuk memajukan masyarakat yang masih agraris ke arah masyarakat industrial. Pengembangan program ini harus berpedoman pada arah pertumbuhan kegiatan non pertanian dalam pendapatan rumah tangga petani. Keberadaan industri di pedesaan tentu menimbulkan dampak bagi masyarakat sekitar. Purwanto (2003) menyebutkan pembangunan industri di pedesaan akan membawa dampak seperti: 1) menyempitnya lahan akibat alih fungsi lahan; 2) arus migrasi masuk; 3) kepadatan penduduk; serta 4) terbukanya peluang kerja dan berusaha di sektor non pertanian.

BPS (2015) menyatakan untuk melihat tingkat kesejahteraan masyarakat suatu wilayah ada beberapa indikator yang dijadikan ukuran, antara lain: 1) Tingkat pendapatan, 2) Akses terhadap pendidikan, 3) Akses terhadap kesehatan, 4) Kondisi tempat tinggal serta fasilitas yang dimiliki, serta 5) Komposisi pengeluaran rumah tangga dengan membandingkan pengeluaran untuk pangan dan non-pangan. Maka dari itu, indikator yang digunakan untuk mengukur tingkat kesejahteraan yang digunakan peneliti adalah tingkat pendapatan, akses terhadap pendidikan, akses terhadap kesehatan, kondisi tempat tinggal serta fasilitas yang dimiliki.

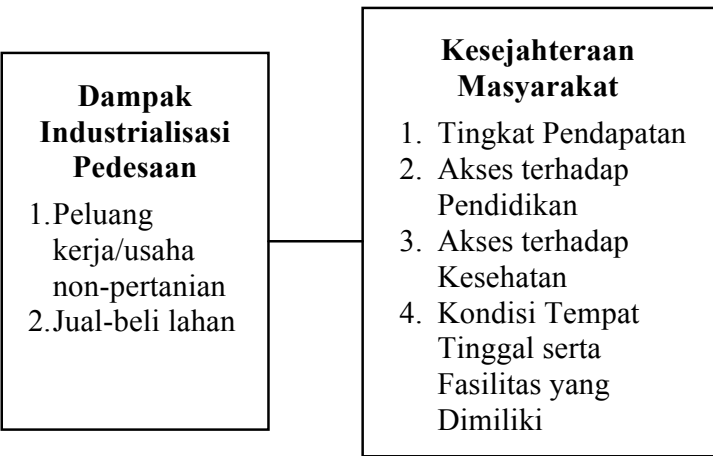

Keterangan:

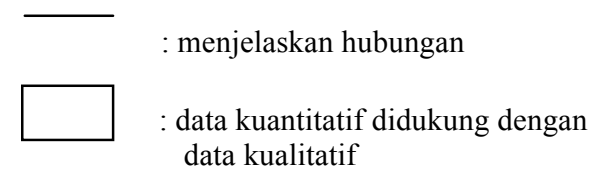

Gambar 1 Kerangka pemikiran dampak industrialisasi pedesaan terhadap kesejahteraan masyarakat

\section{METODOLOGI PENELITIAN}

Penelitian ini menggunakan pendekatan penelitian kuantitatif dengan didukung data kualitatif. Penelitian kuantitatif dilakukan dengan metode survei melalui instrumen kuesioner yang diberikan kepada responden. Pendekatan kuantitatif digunakan untuk menjawab pertanyaan mengenai perubahan yang dialami responden terkait dampak industrialisasi pedesaan dan kesejahteraan masyarakat. Perubahan tersebut diukur dengan melihat kondisi faktual sebelum adanya industri di lokasi penelitian dan setelah adanya industri yaitu tahun 2003. Penelitian ini bersifat ekplanatori karena menjelaskan hubungan antar variabel melalui pengujian hipotesa (Singarimbun dan Effendi 1989). Sementara data kualitatif diperoleh melalui wawancara mendalam kepada informan maupun catatan harian lapang yang dilakukan oleh peneliti di lokasi penelitian. Informasi yang diperoleh melalui pendekatan kualitatif ini digunakan untuk mendukung dan menginterpretasikan data yang didapatkan dari pendekatan kuantitatif mengenai dampak industrialisasi pedesaan, kesejahteraan masyarakat industri dan non-industri, serta hubungan dampak industrialisasi pedesaan 
dengan kesejahteraan masyarakat pelaku industri dan non-industri.

Penelitian dilaksanakan di RW 01 Desa Ciherang Pondok, Kecamatan Caringin, Kabupaten Bogor. Pemilihan lokasi dilakukan secara purposive (sengaja) karena berdasarkan hasil penjajagan yakni:

1. Menurut data literatur Kecamatan Caringin dalam Angka 2013, Desa Ciherang Pondok merupakan desa dengan jumlah industri skala besar terbanyak di Kecamatan Caringin sehingga merupakan desa dengan industrialisme mendalam.

2. Menurut penuturan Sekretaris Desa, kehadiran industri-industri berskala besar dimulai dari tahun 2003 dan berdiri pada lahan yang awalnya merupakan lahan pertanian.

3. Jumlah industri besar di Desa Ciherang Pondok hampir selalu bertambah setiap tahun sehingga lahan pertanian semakin menyempit.

4. RW 01 merupakan daerah yang paling padat penduduknya dan didukung oleh banyaknya usaha-usaha yang dimiliki oleh warganya.

Penelitian ini dilaksanakan mulai dari bulan Juni 2016 sampai dengan Januari 2017.

Unit analisis dalam penelitian ini adalah rumah tangga dengan sasaran pengamatan yaitu pelaku industri maupun non-industri. Responden akan diwawancarai sesuai dengan kuesioner yang telah dibuat karena jawabannya dianggap dapat mewakili kondisinya sebagai masyarakat sekitar industri. Alasan pemilihan unit analisis ini dikarenakan indikator kesejahteraan sangat berkaitan erat dengan rumah tangga.

Populasi dalam penelitian ini adalah penduduk yang berada di RW 01 Desa Ciherang Pondok, Kecamatan Caringin, Kabupaten Bogor. Peneliti sebelumnya membagi populasi ke dalam subpopulasi berdasarkan sumber mata pencahariannya yaitu pekerja industri dan nonindustri sehingga masing-masing subpopulasi menjadi homogen dan setiap anggota populasi memiliki probabilitas yang sama. Kemudian dari populasi tersebut, pemilihan responden dilakukan secara acak terstratifikasi (stratified random sampling). Responden dibagi dalam 30 responden yang bekerja di industri dan 30 responden yang berusaha di bidang non-industri.

Data yang digunakan dalam penelitian ini terdiri dari data primer dan data sekunder. Data yang diolah dan dianalisis yaitu data kuatitatif dan data kualitatif. Data kuantitatif diolah menggunakan aplikasi SPSS version 23 for windows yang digunakan untuk uji statitistik. Pengujian akan dilakukan dengan menggunakan Rank Spearman Correlation untuk menganalisis hubungan antara variabel dampak industrialisasi pedesaan dan tingkat kesejahteraan masyarakat. Sementara data kualitatif dianalisis melalui tiga tahap yaitu reduksi data, penyajian data, dan verifikasi (Singarimbun dan Efendi 1989).

\section{HASIL DAN PEMBAHASAN}

\section{Gambaran Umum Lokasi Penelitian}

Desa Ciherang Pondok merupakan salah satu wilayah desa yang berada di Kecamatan Caringin, Kabupaten Bogor, Provinsi Jawa Barat. Luas wialyah Desa Ciheraang Pondok adalah $427 \mathrm{Ha}$ yang terdiri dari $213 \mathrm{Ha}$ lahan sawah, $77 \mathrm{Ha}$ lahan kering, $10 \mathrm{Ha}$ lahan peternakan, dan sebagian lainnya adalah bangunan, termasuk lahan yang digunakan sebagai industri. Desa ini terbagi dalam 3 Dusun, 5 Rukun Warga (RW) dan 30 Rukun Tetangga (RT).

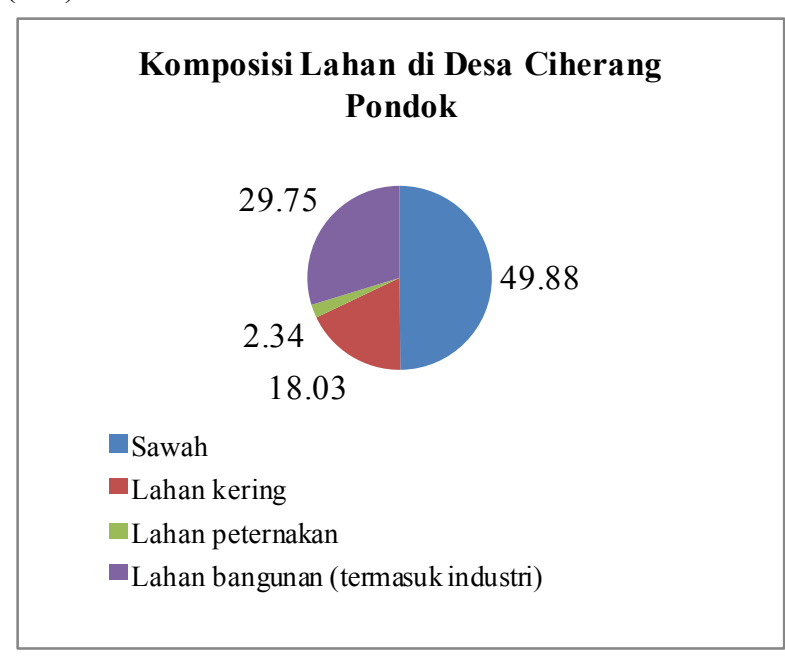

Gambar 2 Komposisi lahan di Desa Ciherang Pondok tahun 2015

Menurut data profil Desa Ciherang Pondok tahun 2015 , terdapat $2.911 \mathrm{KK}$ yang berada di 
wilayah ini dengan total jumlah penduduk sebanyak 11.932 jiwa. Sebaran penduduk menurut kelompok umur disajikan dalam tabel berikut.

Tabel 2 Jumlah dan presentase penduduk menurut kelompok umur di Desa Ciherang Pondok tahun 2015

\begin{tabular}{clcc}
\hline No & $\begin{array}{c}\text { Kelompok } \\
\text { Umur }\end{array}$ & $\begin{array}{c}\text { Jumlah } \\
\text { (jiwa) }\end{array}$ & \% \\
\hline 1 & $0-17$ & 5.161 & 43,25 \\
2 & $18-56$ & 5.460 & 45,76 \\
3 & $\geq 56$ & 1.311 & 10,99 \\
\hline & Jumlah & $\mathbf{1 1 . 9 3 2}$ & $\mathbf{1 0 0 , 0 0}$ \\
\hline
\end{tabular}

Penduduk yang berusia pada rentang 0-17 tahun sebesar 43,25 persen atau sebanyak 5.161 jiwa. Besarnya angka ini dikarenakan tingginya angka kelahiran di Desa Ciherang Pondok. Berbeda selisih 2,52 persen, angka yang tinggi juga ditunjukkan pada penduduk kelompok umur 1856 tahun sebesar 45,76 persen dari total penduduk 11.932 jiwa. Artinya terdapat 5.460 jiwa penduduk usia produktif di Desa Ciherang Pondok. Sedangkan jumlah penduduk yang paling sedikit terdapat pada kelompok umur di atas 56 tahun. Hal ini disebabkan pada umur tersebut sudah banyak penduduk yang meninggal dunia karena semakin tua umur dari seseorang.

Tabel 3 Jumlah dan persentase jenis pekerjaan penduduk Desa Ciherang Pondok tahun 2015

\begin{tabular}{clcc}
\hline No & Jenis Pekerjaan & $\begin{array}{c}\text { Jumlah } \\
\text { (jiwa) }\end{array}$ & $\begin{array}{c}\text { Persentase } \\
\text { (\%) }\end{array}$ \\
\hline 1 & Pegawai Negeri Sipil & 47 & 2,59 \\
2 & TNI/POLRI & 10 & 0,56 \\
3 & Karyawan swasta & 283 & 15,40 \\
4 & Wiraswasta/pedagang & 387 & 21,07 \\
5 & Petani & 90 & 4,91 \\
6 & Buruh tani & 209 & 11,39 \\
7 & Peternak & 150 & 8,18 \\
8 & Jasa & 145 & 7,90 \\
9 & Pengrajin & 128 & 6,98 \\
10 & Pekerja Seni & 1 & 0,07 \\
11 & Pensiunan & 156 & 8,51 \\
12 & Lainnya & 203 & 11,06 \\
13 & Tidak bekerja & 30 & 1,65 \\
\hline & $\quad$ Jumlah & $\mathbf{1 . 8 3 9}$ & $\mathbf{1 0 0 , 0 0}$ \\
\hline
\end{tabular}

Pekerjaan yang dilakukan oleh warga Desa Ciherang Pondok untuk mendapatkan penghasilan dapat dibilang sangat beragam.
Jumlah dan persentase jenis pekerjaan penduduk Desa Ciherang Pondok diringkas dalam Tabel 3.

Penduduk Desa Ciherang Pondok mayoritas bekerja sebagai wiraswasta/pedagang yaitu sebesar 21,07 persen atau 387 jiwa dari total penduduk keseluruhan 1.839 jiwa. Kemudian jumlah karyawan swasta menempati urutan kedua dengan jumlah sebesar 15,40 persen atau 283 jiwa. Dominasi yang ditunjukkan oleh kedua sektor ini menjadikan alasan kuat bagi peneliti untuk melakukan penelitian di wilayah tersebut. Sementara jumlah petani yang ada hanya sebesar 4,91 persen atau sebanyak 90 jiwa untuk mengolah lahan pertanian seluas $213 \mathrm{Ha}$. Hal tersebut menunjukkan bahwa sangat sedikit warga yang berminat untuk meneruskan kegiatan bertani dan lebih banyak memilih untuk bekerja pada sektor lain seperti menjadi karyawan swasta di perusahaan maupun berdagang.

Berdasarkan data profil desa yang diperoleh, tingkat pendidikan formal warga Desa Ciherang Pondok pada tahun 2015 masih belum merata. Hal tersebut ditunjukkan dalam tabel 4.

Tabel 4 Jumlah dan persentase tingkat pendidikan penduduk Desa Ciherang Pondok tahun 2015

\begin{tabular}{|c|c|c|c|}
\hline No & $\begin{array}{c}\text { Lulusan Pendidikan } \\
\text { Formal }\end{array}$ & $\begin{array}{c}\text { Jumlah } \\
\text { (jiwa) }\end{array}$ & $\begin{array}{l}\text { Persentase } \\
(\%)\end{array}$ \\
\hline 1 & Tidak Bersekolah & 152 & 5,60 \\
\hline 2 & $\begin{array}{l}\text { Tidak Tamat Sekolah } \\
\text { Dasar }\end{array}$ & 315 & 11,62 \\
\hline 3 & $\begin{array}{l}\text { Sekolah } \\
\text { Dasar/sederajat }\end{array}$ & 1.275 & 47,00 \\
\hline 4 & SMP/sederajat & 200 & 7,36 \\
\hline 5 & SMA/sederajat & 667 & 24,58 \\
\hline 6 & Akademi D1-D3 & 55 & 2,03 \\
\hline 7 & Sarjana S1 & 30 & 1,11 \\
\hline 8 & Sarjana S2 & 10 & 0,37 \\
\hline 9 & Sarjana S3 & 9 & 0,33 \\
\hline & Jumlah & 2.713 & 100,00 \\
\hline
\end{tabular}

Di bidang kesehatan, akses penduduk terhadap fasilitas kesehatan dapat dibilang masih minim. Hal tersebut ditunjukkan dengan jumlah dokter umum hanya satu orang, bidan serta dukun bayi terlatih berjumlah lima orang, perawat sebanyak satu orang dan tenaga kesehatan lainnya seperti mantri berjumlah dua orang. Kondisi jumlah tenaga kesehatan tersebut jika dibandingkan dengan jumlah penduduk Desa Ciherang Pondok yang mencapai 11.932 jiwa dapat dikatakan 
masih belum proporsional. Pada tahun 2003 PT Kreasi Mas Indah yang bergerak di bidang industri pengolahan minuman berdiri di Desa Ciherang Pondok. Setelah kemunculan perusahaan tersebut, mulai banyak bermunculan pabrik-pabrik di desa ini.

Tabel 5 Jumlah dan persentase industri di tiap desa Kecamatan Caringin, Kabupaten Bogor tahun 2013

\begin{tabular}{|c|c|c|c|}
\hline No & Desa & $\begin{array}{l}\text { Jumlah } \\
\text { Industri }\end{array}$ & $\begin{array}{c}\text { Persentase } \\
(\%)\end{array}$ \\
\hline 1 & Pasir Buncir & 1 & 3,85 \\
\hline 2 & Cinagara & 1 & 3,85 \\
\hline 3 & Tangkil & 0 & 0,00 \\
\hline 4 & Pasir Muncang & 4 & 15,38 \\
\hline 5 & Muara Jaya & 3 & 11,54 \\
\hline 6 & Caringin & 4 & 15,38 \\
\hline 7 & Lemah Duhur & 0 & 0,00 \\
\hline 8 & Cimande & 1 & 3,85 \\
\hline 9 & Pancawati & 2 & 7,69 \\
\hline 10 & Ciderum & 0 & 0,00 \\
\hline 11 & Ciherang Pondok & 7 & 26,92 \\
\hline \multirow[t]{2}{*}{12} & Cimande Hilir & 3 & 11,54 \\
\hline & Jumlah & 26 & 100,00 \\
\hline
\end{tabular}

Data yang tercatat pada BPS Kabupaten Bogor menunjukkan bahwa hingga tahun 2013, Desa Ciherang Pondok merupakan desa dengan jumlah industri terbanyak jika dibandingkan dengan desa lainnya se-Kecamatan Caringin. Artinya, Ciherang Pondok saat ini merupakan desa dengan industrialisme mendalam.

Sementara data yang tercatat pada profil desa menyebutkan bahwa sampai dengan tahun 2016, terdapat sembilan industri berskala besar dan sedang yang bergerak di berbagai jenis usaha.

Tabel 6 Nama, jenis dan skala industri di Desa Ciherang Pondok tahun 2016

\begin{tabular}{|c|c|c|c|}
\hline No & Nama Industri & $\begin{array}{c}\text { Jenis } \\
\text { Industri }\end{array}$ & $\begin{array}{c}\text { Skala } \\
\text { Industri }\end{array}$ \\
\hline 1 & PT Kreasi Mas Indah & Minuman & Besar \\
\hline 2 & $\begin{array}{l}\text { PT Tirta Investama } \\
\text { (AQUA) }\end{array}$ & Minuman & Besar \\
\hline 3 & PT Kalbe Milko & $\begin{array}{l}\text { Minuman } \\
\text { Alat }\end{array}$ & Besar \\
\hline 4 & PT Dragon I \& II & $\begin{array}{l}\text { pembersih } \\
\text { rumah } \\
\text { tangga }\end{array}$ & Besar \\
\hline 5 & PT Malvel Indo Abadi & Boneka & Sedang \\
\hline 6 & PT Liliana & Pakaian jadi & Besar \\
\hline 7 & $\begin{array}{l}\text { PT Tri Cahaya } \\
\text { Mitratama }\end{array}$ & $\begin{array}{l}\text { Impor- } \\
\text { Ekspor }\end{array}$ & Besar \\
\hline 8 & $\begin{array}{l}\text { PT Tirta Fresindo Jaya } \\
\text { (Mayora) }\end{array}$ & Minuman & Besar \\
\hline 9 & $\begin{array}{l}\text { PT Milko Beverage } \\
\text { Industry }\end{array}$ & Minuman & Besar \\
\hline
\end{tabular}

Sumber: Data Profil Desa Ciherang Pondok 2015

\section{Hubungan Peluang Kerja atau Usaha Non Pertanian dengan Tingkat Pendapatan}

Peluang kerja atau usaha non pertanian diukur dengan melihat keragaman lapangan pekerjaan di bidang non pertanian saat sebelum dan setelah adanya industri. Selain itu, peluang kerja atau usaha non pertanian juga diukur dengan melihat adakah perubahan pekerjaan responden dari sektor pertanian ke non pertanian. Hal lainnya yang diukur adalah peran pekerjaan dalam mencukupi kebutuhan hidup sebelum dan setelah adanya industri, serta kemudahan dalam bekerja maupun menciptakan usaha saat sebelum dan setelah hadirnya industri.

Tabel 7 Jumlah dan persentase tingkat peluang kerja/ usaha non pertanian dan tingkat pendapatan masyarakat di Desa Ciherang Pondok tahun 2016

\begin{tabular}{|c|c|c|c|c|c|c|c|}
\hline \multirow{3}{*}{ Responden } & \multirow{3}{*}{$\begin{array}{c}\text { Peluang Kerja/ } \\
\text { Usaha }\end{array}$} & \multicolumn{4}{|c|}{ Tingkat Pendapatan } & \multirow{2}{*}{\multicolumn{2}{|c|}{ Total }} \\
\hline & & \multicolumn{2}{|c|}{ Tetap } & \multicolumn{2}{|c|}{ Meningkat } & & \\
\hline & & $\mathbf{n}$ & $\%$ & $\mathbf{n}$ & $\%$ & $\sum$ & $\%$ \\
\hline \multirow[t]{3}{*}{ Industri } & Tetap & 6 & 20,0 & 0 & 0,0 & 6 & 20,0 \\
\hline & Meningkat & 1 & 3,3 & 23 & 76,7 & 24 & 80,0 \\
\hline & Total & 7 & 23,3 & 23 & 76,7 & 30 & 100,0 \\
\hline \multirow{3}{*}{$\begin{array}{l}\text { Non } \\
\text { Industri }\end{array}$} & Tetap & 3 & 10,0 & 0 & 0 & 3 & 10,0 \\
\hline & Meningkat & 7 & 23,3 & 20 & 66,7 & 27 & 90,0 \\
\hline & Total & 10 & 33,3 & 20 & 66,7 & 30 & 100,0 \\
\hline
\end{tabular}

Koefisien korelasi industri $=0.906$.

Nilai signifikansi $=0.000$

Koefisien korelasi non industri $=0.205$.

Nilai signifikansi $=0.277$

Sementara tingkat pendapatan responden sebelum dan setelah industri diukur dengan melihat perubahan pendapataan yang riil terjadi pada masing-masing responden, apakah terjadi 
perubahan menurun, tetap atau perubahan meningkat. Selain itu, indikator lainnya yang dipilih adalah dengan mengacu pada UMR Kabupaten Bogor, apakah responden memiliki pendapatan di bawah, setara ataupun di atas UMR.

Berdasarkan uji korelasi menggunakan rank spearman diperoleh nilai koefisien korelasi sebesar 0.906 dan nilai signifikasi 0.000 . Menurut Sarwono (2009) jika nilai koefisien korelasi berada diantara $>$ 0.75-0.99 maka terdapat hubungan yang sangat kuat. Sedangkan jika nilai signifikasi lebih kecil dari taraf $\alpha$ (0.05) yaitu $0.000<0.05$ maka dapat disimpulkan terdapat korelasi yang signifikan antara peluang kerja dan tingkat pendapatan pada kelompok responden industri.

"Perubahan setelah adanya industri dalam hal pendapatan sangat terasa. Dahulu saya yang belum bekerja tidak memiliki pendapatan, sekarang sudah di atas UMR.” (ILH, 27 tahun)

Sementara pada kelompok responden non industri, diperoleh nilai koefisien korelasi sebesar 0.205 dan nilai signifikasi 0.277 . Menurut Sarwono (2009) jika nilai koefisien korelasi berada diantara 0-0.25 maka terdapat hubungan yang sangat lemah. Sedangkan jika nilai signifikasi lebih besar dari taraf $\alpha(0.05)$ yaitu $0.277>0.05$ maka dapat disimpulkan tidak terdapat korelasi yang signifikan antara peluang usaha dan tingkat pendapatan.

"Dahulu saya hanya ibu rumah tangga yang tidak memiliki pekerjaan selain mengurus rumah dan anak. Hadirnya pabrik-pabrik telah memberikan peluang bagi saya mempunyai usaha warung sembako untuk membantu suami. Walaupun kecil-kecilan, saya memiliki pendapatan. Namun jika ditanyakan apakah di atas UMR, jawabannya adalah belum." (KOM, 43 tahun)

\section{Hubungan Peluang Kerja atau Usaha Non Pertanian dengan Akses Pendidikan}

Sub-bab ini akan memaparkan hasil penelitian mengenai hubungan peluang kerja atau usaha non pertanian dengan akses pendidikan sebagai salah satu indikator kesejahteraan masyarakat. Akses terhadap pendidikan dilihat dari kemampuan responden maupun anggota keluarga menyelesaikan pendidikannya saat sebelum dan setelah hadirnya industri. Penelitian bertujuan untuk mengetahui apakah terjadi perubahan kondisi. Tingkat pendidikan dalam penelitian ini adalah Sekolah Dasar (SD) atau sederajat, Sekolah Menengah Pertama (SMP) atau sederajat, Sekolah Menengah Atas (SMA) atau sederajat dan Perguruan Tinggi.

Tabel 8 Jumlah dan persentase tingkat peluang kerja/usaha non pertanian dan akses pendidikan masyarakat di Desa Ciherang Pondok tahun 2016

\begin{tabular}{|c|c|c|c|c|c|c|c|}
\hline \multirow{3}{*}{ Responden } & \multirow{3}{*}{$\begin{array}{c}\text { Peluang } \\
\text { Kerja/ } \\
\text { Usaha }\end{array}$} & \multicolumn{4}{|c|}{ Akses Pendidikan } & \multirow{2}{*}{\multicolumn{2}{|c|}{ Total }} \\
\hline & & \multicolumn{2}{|c|}{ Tetap } & \multicolumn{2}{|c|}{ Meningkat } & & \\
\hline & & $\mathbf{n}$ & $\%$ & $n$ & $\%$ & $\sum$ & $\%$ \\
\hline \multirow{3}{*}{ Industri } & Tetap & 6 & 20,0 & 0 & 0,0 & 6 & 20 \\
\hline & Meningkat & 11 & 36,7 & 13 & 43,3 & 24 & 80 \\
\hline & Total & 17 & 56,7 & 13 & 43,3 & 30 & 100 \\
\hline \multirow{3}{*}{$\begin{array}{l}\text { Non } \\
\text { Industri }\end{array}$} & Tetap & 3 & 10,0 & 0 & 0,0 & 3 & 10 \\
\hline & Meningkat & 26 & 86,7 & 1 & 3,3 & 27 & 90 \\
\hline & Total & 29 & 96,7 & 1 & 3,3 & 30 & 100 \\
\hline
\end{tabular}

Koefisien korelasi industri $=0.709$.

Nilai signifikansi $=0.000$

Koefisien korelasi non industri $=0.062$.

Nilai signifikansi $=0.745$

Berdasarkan uji korelasi menggunakan rank spearman diperoleh nilai koefisien korelasi sebesar 0.709 dan nilai signifikasi 0.000 . Menurut Sarwono (2009) jika nilai koefisien korelasi berada diantara $>$ 0.5-0.75 maka terdapat hubungan yang kuat. Sedangkan jika nilai signifikasi lebih kecil dari taraf $\alpha(0.05)$ yaitu $0.000<0.05$ maka dapat disimpulkan terdapat korelasi yang signifikan antara peluang kerja dan akses pendidikan pada kelompok responden industri.
"Walaupun hadirnya industri memang diprioritaskan untuk mempekerjakan karyawan dari daerah sekitar, namun tidak semua bisa masuk begitu saja. Tetap calon karyawan itu harus memenuhi syarat dari perusahaan. Biasanya perusahaan merekrut lulusan SMA. Tapi bagi mereka yang tidak memiliki ijazah SMA bisa mengikuti ujian paket C sebagai alternatif." (ENH, 45 tahun)

Sementara pada kelompok responden non industri, diperoleh nilai koefisien korelasi sebesar 0.062 dan nilai signifikasi 0.745 . Menurut Sarwono (2009) jika nilai koefisien korelasi berada diantara 0-0.25 maka terdapat hubungan yang sangat lemah. Sedangkan jika nilai signifikasi lebih besar dari taraf $\alpha(0.05)$ yaitu $0.745>0.05$ maka dapat disimpulkan tidak 
terdapat korelasi yang signifikan antara peluang usaha dan akses pendidikan.

“... dengan kondisi seperti ini (bekerja sebagai penyediaan makanan/warung nasi) yang penting punya penghasilan sudah cukup. Tidak perlu sekolah lebih tinggi." (TUT, 37 tahun)

\section{Hubungan Peluang Kerja atau Usaha Non Pertanian dengan Akses Kesehatan}

Tujuan lainnya dari penelitian ini adalah untuk membuktikan hipotesis mengenai hubungan peluang kerja atau usaha non pertanian dengan akses kesehatan pada responden industri maupun non industri. Akses kesehatan dalam penelitian ini adalah bagaimana kondisi kesehatan responden serta fasilitas maupun tenaga kesehatan apa yang responden pilih saat sebelum dan setelah adanya industri di Desa Ciherang Pondok yang terdiri dari mantri, dokter serta rumah sakit.

Berdasarkan uji korelasi menggunakan rank spearman diperoleh nilai koefisien korelasi sebesar 0.192 dan nilai signifikasi 0.309 . Menurut Sarwono (2009) jika nilai koefisien korelasi berada diantara 0-0.25 maka terdapat hubungan yang sangat lemah. Sedangkan jika nilai signifikasi lebih besar dari taraf $\alpha(0.05)$ yaitu $0.309>0.05$ maka dapat disimpulkan tidak terdapat korelasi yang signifikan antara peluang kerja dan akses kesehatan pada kelompok responden industri.
"Walaupun terbukanya peluang bagi saya untuk bekerja di pabrik dan mendapatkan jaminan kesehatan, terkadang saya malas untuk menggunakan jaminan dari perusahaan dan pergi ke rumah sakit. Hal ini dikarenakan jaraknya jauh sehingga tetap harus mengeluarkan biaya untuk ongkos. Jadi lebih baik tetap di praktek dokter saja yang dekat dari rumah." (RID, 25 tahun)

Sementara pada kelompok responden non industri, diperoleh nilai koefisien korelasi sebesar 0.005 dan nilai signifikasi 0.978 . Menurut Sarwono (2009) jika nilai koefisien korelasi berada diantara 0-0.25 maka terdapat hubungan yang sangat lemah. Sedangkan jika nilai signifikasi lebih besar dari taraf $\alpha(0.05)$ yaitu $0.978>0.05$ maka dapat disimpulkan tidak terdapat korelasi yang signifikan antara peluang usaha dan akses kesehatan.

"Kalau ke rumah sakit mah jauh, harus ngeluarin biaya lagi buat ongkosnya. Jadi lebih baik berobat ke dokter saja karena dekat dan tidak terlalu mahal." (YAY, 53 tahun)

Tabel 9 Jumlah dan persentase tingkat peluang kerja/ usaha non pertanian dan akses kesehatan masyarakat di Desa Ciherang Pondok tahun 2016

\begin{tabular}{|c|c|c|c|c|c|c|c|}
\hline \multirow{3}{*}{ Responden } & \multirow{3}{*}{$\begin{array}{c}\text { Peluang Kerja/ } \\
\text { Usaha }\end{array}$} & \multicolumn{4}{|c|}{ Akses Kesehatan } & \multirow{2}{*}{\multicolumn{2}{|c|}{ Total }} \\
\hline & & \multicolumn{2}{|c|}{ Tetap } & \multicolumn{2}{|c|}{ Meningkat } & & \\
\hline & & n & $\%$ & $\mathbf{n}$ & $\%$ & $\sum$ & $\%$ \\
\hline \multirow{3}{*}{ Industri } & Tetap & 6 & 20,0 & 0 & 0,0 & 6 & 20,0 \\
\hline & Meningkat & 1 & 3,3 & 23 & 76,7 & 24 & 80,0 \\
\hline & Total & 7 & 23,3 & 23 & 76,7 & 30 & 100,0 \\
\hline \multirow{3}{*}{$\begin{array}{l}\text { Non } \\
\text { Industri }\end{array}$} & Tetap & 3 & 10,0 & 0 & 0,0 & 3 & 10,0 \\
\hline & Meningkat & 8 & 26,7 & 19 & 63,3 & 27 & 90,0 \\
\hline & Total & 11 & 36,7 & 19 & 63,3 & 30 & 100,0 \\
\hline
\end{tabular}

Koefisien korelasi industri $=0.192$.

Nilai signifikansi $=0.309$

Koefisien korelasi non industri $=0.005$.

Nilai signifikansi $=0.978$

Hubungan Peluang Kerja atau Usaha Non Pertanian dengan Kondisi Tempat Tinggal serta Fasilitas yang Dimiliki

Indikator lain yang digunakan untuk mengukur tingkat kesejahteraan masyarakat adalah dengan melihat kondisi tempat tinggal dan fasilitas yang dimiliki.
Berdasarkan uji korelasi menggunakan rank spearman diperoleh nilai koefisien korelasi sebesar 0.605 dan nilai signifikasi 0.000 . Menurut Sarwono (2009) jika nilai koefisien korelasi berada diantara $>$ 0.5-0.75 maka terdapat hubungan yang kuat. Sedangkan jika nilai signifikasi lebih kecil dari taraf $\alpha(0.05)$ yaitu $0.000<0.05$ maka dapat disimpulkan 
terdapat korelasi yang signifikan antara peluang kerja dan kondisi tempat tinggal serta fasilitas yang dimiliki pada kelompok responden industri.

"Setelah bekerja di pabrik saya bisa membeli motor sendiri walaupun masih mencicil dengan sistem kredit." (IRP, 26 tahun)

Sementara pada kelompok responden non industri, diperoleh nilai koefisien korelasi sebesar 0.116 dan nilai signifikasi 0.542 . Menurut Sarwono (2009) jika nilai koefisien korelasi berada diantara 0-0.25 maka terdapat hubungan yang sangat lemah. Sedangkan jika nilai signifikasi lebih besar dari taraf $\alpha(0.05)$ yaitu $0.542>0.05$ maka dapat disimpulkan tidak terdapat korelasi yang signifikan antara peluang usaha dan kondisi tempat tinggal serta fasilitas yang dimiliki.

"Setelah adanya industri, saya yang awalnya tidak bekerja saat ini mampu memiliki usaha warung nasi. Namun jika untuk memiliki barang berharga seperti emas dan kendaraan, penghasilan saya belum mampu menutupi itu." (RAH, 35 tahun)

Tabel 10 Jumlah dan persentase tingkat peluang kerja atau usaha non pertanian dan kondisi tempat tinggal serta fasilitas yang dimiliki responden di Desa Ciherang Pondok tahun 2016

\begin{tabular}{|c|c|c|c|c|c|c|c|}
\hline \multirow{3}{*}{ Responden } & \multirow{3}{*}{$\begin{array}{c}\text { Peluang Kerja/ } \\
\text { Usaha }\end{array}$} & \multicolumn{4}{|c|}{ Tempat Tinggal \& Fasilitas } & \multirow{2}{*}{\multicolumn{2}{|c|}{ Total }} \\
\hline & & & & & & & \\
\hline & & $\mathbf{n}$ & $\%$ & $\mathbf{n}$ & $\%$ & $\sum$ & $\%$ \\
\hline \multirow{3}{*}{ Industri } & Tetap & 6 & 20,0 & 0 & 0,0 & 6 & 20,0 \\
\hline & Meningkat & 2 & 6,7 & 22 & 73,3 & 24 & 80,0 \\
\hline & Total & 8 & 26,7 & 22 & 73,3 & 30 & 100,0 \\
\hline \multirow{3}{*}{$\begin{array}{l}\text { Non } \\
\text { Industri }\end{array}$} & Tetap & 3 & 10,0 & 0 & 0,0 & 3 & 10,0 \\
\hline & Meningkat & 10 & 33,3 & 17 & 56,7 & 27 & 90,0 \\
\hline & Total & 13 & 43,3 & 17 & 56,7 & 30 & 100,0 \\
\hline
\end{tabular}

Koefisien korelasi industri $=0.605$.

Nilai signifikansi $=0.000$

Koefisien korelasi non industri $=0.116$.

Nilai signifikansi $=0.542$

\section{Hubungan Jual Beli Lahan dengan Tingkat Pendapatan}

Aktivitas jual-beli lahan merupakan dampak lain atas hadirnya industri di pedesaan. Bagian ini akan menjelaskan hubungan jual-beli lahan dengan tingkat pendapatan sebagai salah satu indikator kesejahteraan masyarakat. Kegiatan jual-beli lahan diukur dari pernah atau tidaknya menjual atau membeli lahan pada periode waktu sebelum dan setelah adanya industri, luas lahan yang diperjualbelikan, serta peruntukkan lahan bagi kegiatan non pertanian.

Berdasarkan uji korelasi menggunakan rank spearman diperoleh nilai koefisien korelasi sebesar 0.216 dan nilai signifikasi 0.251 . Menurut Sarwono (2009) jika nilai koefisien korelasi berada diantara 0-0.25 maka terdapat hubungan yang sangat lemah. Sedangkan jika nilai signifikasi lebih besar dari taraf $\alpha(0.05)$ yaitu $0.251>0.05$ maka dapat disimpulkan tidak terdapat korelasi yang signifikan antara jual-beli lahan dan tingkat pendapatan pada kelompok responden industri.
Tabel 11 Jumlah dan persentase tingkat jual beli lahan dan tingkat pendapatan masyarakat di Desa Ciherang Pondok tahun 2016

\begin{tabular}{|c|c|c|c|c|c|c|c|}
\hline \multirow{3}{*}{ Responden } & \multirow{3}{*}{$\begin{array}{c}\text { Jual } \\
\text { Beli } \\
\text { Lahan }\end{array}$} & \multicolumn{4}{|c|}{ Tingkat Pendapatan } & \multirow{2}{*}{\multicolumn{2}{|c|}{ Total }} \\
\hline & & \multicolumn{2}{|c|}{ Tetap } & \multicolumn{2}{|c|}{ Meningkat } & & \\
\hline & & $\sum$ & $\%$ & $\sum$ & $\%$ & $\sum$ & $\%$ \\
\hline \multirow{3}{*}{ Industri } & Tetap & 7 & 23,3 & 19 & 63,3 & 26 & 86,7 \\
\hline & $\begin{array}{l}\text { Mening- } \\
\text { kat }\end{array}$ & 0 & 0,0 & 4 & 13,4 & 5 & 13,3 \\
\hline & Total & 7 & 23,3 & 23 & 76,7 & 30 & 100,0 \\
\hline \multirow{3}{*}{$\begin{array}{l}\text { Non } \\
\text { Industri }\end{array}$} & Tetap & 10 & 33,3 & 16 & 53,4 & 26 & 86,7 \\
\hline & $\begin{array}{l}\text { Mening- } \\
\text { kat }\end{array}$ & 0 & 0,0 & 4 & 13,3 & 4 & 13,3 \\
\hline & Total & 10 & 33,3 & 20 & 66,7 & 30 & $\mathbf{1 0 0 , 0}$ \\
\hline
\end{tabular}

Koefisien korelasi industri $=0.216$

Nilai signifikansi $=0.251$

Koefisien korelasi non industri $=0.277$.

Nilai signifikansi $=0.138$

“Tanpa melakukan jual-beli lahan saya sudah mengalami peningkatan pendapatan dibandingkan sebelum adanya industri. Hal ini karena gaji yang saya dapatkan dari pekerjaan di pabrik sudah berada di atas UMR.” (ILH, 27 tahun)

Sementara pada kelompok responden non industri, diperoleh nilai koefisien korelasi 
sebesar 0.277 dan nilai signifikasi 0.138 . Menurut Sarwono (2009) jika nilai koefisien korelasi berada diantara $>$ 0.25-0.5 maka terdapat hubungan yang cukup kuat. Sedangkan jika nilai signifikasi lebih besar dari taraf $\alpha$ $(0.05)$ yaitu $0.138>0.05$ maka dapat disimpulkan tidak terdapat korelasi yang signifikan antara jual-beli lahan dan tingkat pendapatan.

"Setelah adanya pabrik-pabrik, tanpa melakukan jual-beli lahan saya sudah mengalami peningkatan pendapatan dibandingkan sebelum adanya industri. Hal ini karena toko yang saya miliki selalu ramai pembeli. Kalau dihitung alhamdulillah sudah di atas UMR” (NRD, 41 tahun)

\section{Hubungan Jual Beli Lahan dengan Akses Pendidikan}

Pengujian hipotesis lainnya dalam penelitian ini adalah untuk mengetahui hubungan antara jualbeli lahan dengan akses terhadap pendidikan yang dialami oleh responden. Perubahan kondisi sebelum dan setelah hadirnya industri dilihat dari aktivitas jual-beli lahan yang dilakukan serta perubahan dalam akses pendidikan.

Tabel 12 Jumlah dan persentase tingkat jual beli lahan dan akses pendidikan masyarakat di Desa Ciherang Pondok tahun 2016

\begin{tabular}{|c|c|c|c|c|c|c|c|}
\hline \multirow{3}{*}{ Responden } & \multirow{3}{*}{$\begin{array}{c}\text { Jual } \\
\text { Beli } \\
\text { Lahan }\end{array}$} & \multicolumn{4}{|c|}{ Akses Pendidikan } & \multirow{2}{*}{\multicolumn{2}{|c|}{ Total }} \\
\hline & & \multicolumn{2}{|c|}{ Tetap } & \multicolumn{2}{|c|}{ Meningkat } & & \\
\hline & & $\Sigma$ & $\%$ & $\sum$ & $\%$ & $\Sigma$ & $\%$ \\
\hline \multirow{3}{*}{ Industri } & Tetap & 17 & 56,7 & 9 & 30,0 & 26 & 86,7 \\
\hline & $\begin{array}{l}\text { Mening- } \\
\text { kat }\end{array}$ & 0 & 0,0 & 4 & 13,3 & 4 & 13,3 \\
\hline & Total & 17 & 56,7 & 13 & 43,3 & 30 & 100,0 \\
\hline \multirow{3}{*}{$\begin{array}{l}\text { Non } \\
\text { Industri }\end{array}$} & Tetap & 26 & 86,7 & 0 & 0,0 & 26 & 86,7 \\
\hline & $\begin{array}{l}\text { Mening- } \\
\text { kat }\end{array}$ & 3 & 10,0 & 1 & 3,3 & 4 & 13,3 \\
\hline & Total & 29 & 96,7 & 1 & 3,3 & 30 & 100,0 \\
\hline
\end{tabular}

Koefisien korelasi industri $=0.449$.

Nilai signifikansi $=0.013$

Koefisien korelasi non industri $=0.473$.

Nilai signifikansi $=0.008$

Berdasarkan uji korelasi menggunakan rank spearman diperoleh nilai koefisien korelasi sebesar 0.449 dan nilai signifikasi 0.013 . Menurut Sarwono (2009) jika nilai koefisien korelasi berada diantara $>$ 0.25-0.5 maka terdapat hubungan yang cukup kuat. Sedangkan jika nilai signifikasi lebih kecil dari taraf $\alpha$ (0.05) yaitu $0.013<0.05$ maka dapat disimpulkan terdapat korelasi yang signifikan antara jual-beli lahan dan akses pendidikan pada kelompok responden industri.

"Setelah orangtua saya menjual lahan ke
perusahaan untuk didirikan pabrik, sebagian
uangnya digunakan untuk biaya sekolah saya
melanjutkan SMA.” (ASR, 28 tahun)

Sementara pada kelompok responden non industri, diperoleh nilai koefisien korelasi sebesar 0.473 dan nilai signifikasi 0.008 . Menurut Sarwono (2009) jika nilai koefisien korelasi berada diantara $>0.25-0.5$ maka terdapat hubungan yang cukup kuat. Sedangkan jika nilai signifikasi lebih kecil dari taraf $\alpha$ (0.05) yaitu $0.008<0.05$ maka dapat disimpulkan terdapat korelasi yang signifikan antara jual-beli lahan dan akses pendidikan.

"Setelah melakukan penjualan lahan untuk
dijadikan pabrik dan pembelian lahan untuk
saya bangun bisnis kontrakan, saya mampu
membiayai anak hingga lulus kuliah." (HAB,
55 tahun)

"Setelah melakukan penjualan lahan untuk dijadikan pabrik dan pembelian lahan untuk membiayai anak hingga lulus kuliah." (HAB, 55 tahun)

Tabel 13 Jumlah dan persentase tingkat jual beli lahan dan akses kesehatan masyarakat di Desa Ciherang Pondok tahun 2016

\begin{tabular}{|c|c|c|c|c|c|c|c|}
\hline \multirow{3}{*}{ Responden } & \multirow{3}{*}{ Jual Beli Lahan } & \multicolumn{4}{|c|}{ Akses Kesehatan } & \multirow{2}{*}{\multicolumn{2}{|c|}{ Total }} \\
\hline & & \multicolumn{2}{|c|}{ Tetap } & \multicolumn{2}{|c|}{ Meningkat } & & \\
\hline & & $\Sigma$ & $\%$ & $\Sigma$ & $\%$ & $\Sigma$ & $\%$ \\
\hline \multirow{3}{*}{ Industri } & Tetap & 7 & 23,3 & 19 & 63,4 & 26 & 86,7 \\
\hline & Meningkat & 0 & 0,0 & 4 & 13,3 & 4 & 13,3 \\
\hline & Total & 7 & 23,3 & 23 & 76,7 & 30 & 100,0 \\
\hline \multirow{3}{*}{$\begin{array}{l}\text { Non } \\
\text { Industri }\end{array}$} & Tetap & 10 & 33,4 & 16 & 53,3 & 26 & 86,7 \\
\hline & Meningkat & 1 & 3,3 & 3 & 10,0 & 4 & 13,3 \\
\hline & Total & 11 & 36,7 & 19 & 63,3 & 30 & 100,0 \\
\hline
\end{tabular}

Koefisien korelasi industri $=0.216$.

Signifikansi $=0.251$

Koefisien korelasi non industri $=0.010$. signifikansi $=0.959$ 


\section{Hubungan Jual Beli Lahan dengan Akses Kesehatan}

Bagian ini akan menjelaskan hubungan antara variabel jual-beli lahan dan akses terhadap kesehatan. Masing-masing variabel tersebut diukur dengan melihat kondisi sebelum dan setelah adanya industri. Hasil penelitian menunjukkan bahwa tidak terdapat perbedaan signifikan yang dialami oleh kelompok responden industri maupun kelompok responden non industri. Berdasarkan uji korelasi menggunakan rank spearman diperoleh nilai koefisien korelasi sebesar 0.216 dan nilai signifikasi 0.251. Menurut Sarwono (2009) jika nilai koefisien korelasi berada diantara $0-0.25$ maka terdapat hubungan yang sangat lemah. Sedangkan jika nilai signifikasi lebih besar dari taraf $\alpha(0.05)$ yaitu $0.251>0.05$ maka dapat disimpulkan tidak terdapat korelasi yang signifikan antara jual-beli lahan dan akses kesehatan pada kelompok responden industri.

"Saya tidak melakukan kegiatan jual-beli lahan, namun mengalami peningkatan fasilitas kesehatan karena mendapatkan jaminan rumah sakit dari perusahaan." (IND, 28 tahun)

Sementara pada kelompok responden non industri, diperoleh nilai koefisien korelasi sebesar 0.010 dan nilai signifikasi 0.959 . Menurut Sarwono (2009) jika nilai koefisien korelasi berada diantara 0-0.25 maka terdapat hubungan yang sangat lemah. Sedangkan jika nilai signifikasi lebih besar dari taraf $\alpha(0.05)$ yaitu $0.959>0.05$ maka dapat disimpulkan tidak terdapat korelasi yang signifikan antara jual-beli lahan dan akses kesehatan.
"Dahulu untuk berobat rata-rata warga di sini pergi ke mantri. Namun setelah adanya industri, terdapat praktek dokter di Desa Ciherang Pondok sehingga banyak warga yang beralih untuk berobat ke dokter. Tanpa melakukan jual-beli lahan juga saya sudah mampu berobat ke dokter. " (CIH, 48 tahun)

\section{Hubungan Jual Beli Lahan dengan Kondisi Tempat Tinggal serta Fasilitas yang Dimiliki}

Pengujian lain yang dilakukan dalam penelitian mengenai dampak industrialisasi pedesaan terhadap tingkat kesejahteraan masyarakat adalah dengan melihat hubungan antara tingkat jual-beli lahan dengan kondisi tempat tinggal serta fasilitas yang dimiliki. Hasil penelitian menunjukkan bahwa terdapat perbedaan antara kelompok responden industri dan non industri dalam perubahan kondisi tempat tinggal serta fasilitas yang dimiliki sebelum dan setelah hadirnya industri di Desa Ciherang Pondok, Kabupaten Bogor.

Berdasarkan uji korelasi menggunakan rank spearman diperoleh nilai koefisien korelasi sebesar 0.237 dan nilai signifikasi 0.208. Menurut Sarwono (2009) jika nilai koefisien korelasi berada diantara 0-0.25 maka terdapat hubungan yang sangat lemah. Sedangkan jika nilai signifikasi lebih besar dari taraf $\alpha(0.05)$ yaitu $0.208>0.05$ maka dapat disimpulkan tidak terdapat korelasi yang signifikan antara jual-beli lahan dan kondisi tempat tinggal serta fasilitas yang dimiliki pada kelompok responden industri.

\footnotetext{
"Saya tidak menjual atau membeli lahan setelah adanya industri... dari usaha yang saya miliki saat ini saya mampu membeli emas dan ponsel." (YAY, 53 tahun)
}

Tabel 14 Jumlah dan persentase tingkat jual beli lahan dan kondisi tempat tinggal serta fasilitas yang dimiliki responden di Desa Ciherang Pondok tahun 2016

\begin{tabular}{|c|c|c|c|c|c|c|c|}
\hline \multirow{3}{*}{ Responden } & \multirow{3}{*}{ Jual Beli Lahan } & \multicolumn{4}{|c|}{ Tempat Tinggal \& Fasilitas } & \multirow{2}{*}{\multicolumn{2}{|c|}{ Total }} \\
\hline & & \multicolumn{2}{|c|}{ Tetap } & \multicolumn{2}{|c|}{ Meningkat } & & \\
\hline & & $\Sigma$ & $\%$ & $\sum$ & $\%$ & $\sum$ & $\%$ \\
\hline \multirow{3}{*}{ Industri } & Tetap & 8 & 26,7 & 18 & 60,0 & 26 & 86,7 \\
\hline & Meningkat & 0 & 0,0 & 4 & 13,3 & 4 & 13,3 \\
\hline & Total & 8 & 26,7 & 22 & 73,3 & 30 & 100,0 \\
\hline \multirow{3}{*}{$\begin{array}{l}\text { Non } \\
\text { Industri }\end{array}$} & Tetap & 13 & 43,3 & 13 & 43,4 & 26 & 86,7 \\
\hline & Meningkat & 0 & 0,0 & 4 & 13,3 & 4 & 13,3 \\
\hline & Total & 13 & 43,3 & 17 & 56,7 & 30 & 100,0 \\
\hline
\end{tabular}

Koefisien korelasi industri $=0.237$.

Nilai signifikansi $=0.208$

Koefisien korelasi non industri $=0.590$.

Nilai signifikansi $=0.001$ 
Sementara pada kelompok responden non industri, diperoleh nilai koefisien korelasi sebesar 0.590 dan nilai signifikasi 0.001 . Menurut Sarwono (2009) jika nilai koefisien korelasi berada diantara $>$ 0.5-0.75 maka terdapat hubungan yang kuat. Sedangkan jika nilai signifikasi lebih kecil dari taraf $\alpha(0.05)$ yaitu $0.001<0.05$ maka dapat disimpulkan terdapat korelasi yang signifikan antara jual-beli lahan dan kondisi tempat tinggal serta fasilitas yang dimiliki.

"Setelah melakukan jual-beli lahan, alhamdulillah sekarang saya mampu memiliki mobil pribadi.” (HAM, 49 tahun)

\section{SIMPULAN DAN SARAN}

\section{Simpulan}

Berdasarkan hasil penelitian yang dikemukakan sebelumnya, dapat disimpulkan bahwa:

1. Terdapat perbedaan hubungan dampak industrialisasi pedesaan dengan tingkat kesejahteraan pada masyarakat dengan pola mata pencaharian di bidang industri dan non industri.

2. Pada responden industri, terdapat hubungan antara peluang kerja non pertanian dengan tingkat pendapatan, akses pendidikan, akses kesehatan dan kondisi tempat tinggal serta fasilitas yang dimiliki.

3. Pada responden non industri, tidak terdapat hubungan antara peluang kerja non pertanian dengan tingkat pendapatan, akses pendidikan, akses kesehatan dan kondisi tempat tinggal serta fasilitas yang dimiliki.

4. Tidak terdapat hubungan antara jual beli lahan dengan tingkat pendapatan dan akses kesehatan pada responden industri maupun non industri.

5. Terdapat hubungan antara jual beli lahan dengan akses pendidikan responden industri maupun non industri.

6. Tidak terdapat hubungan antara jual beli lahan dengan kondisi responden tempat tinggal serta fasilitas yang dimiliki responden industri.

7. Terdapat hubungan antara jual beli lahan dengan kondisi tempat tinggal serta fasilitas yang dimiliki responden non industri.

\section{Saran}

Adapun saran yang direkomendasikan bagi masyarakat yang terkena dampak industrialisasi pedesaan adalah sebagai berikut:

1. Masyarakat diupayakan agar lebih selektif dengan pendirian industri baru, lebih memperhatikan lahan pertanian yang semakin sempit dan tidak mudah tergiur oleh keuntungan jangka pendek yang didapat jika menjual lahan khususnya lahan pertanian.

2. Industri besar berorientasi untuk mendapatkan keuntungan sebesar-besarnya dan menekan biaya produksi termasuk upah karyawan seminimal mungkin. Oleh karena itu, masyarakat harus terus aktif meningkatkan pendidikan dan keterampilan dalam rangka mengatasi kemungkinan tergesernya masyarakat setempat dari kegiatan pengembangan industri.

3. Masyarakat diupayakan agar lebih kritis dan memiliki kemampuan negosiasi dengan perusahaan maupun pemerintah desa dalam menanggapi kegiatan industri yang mengganggu kondisi kesehatan masyarakat sekitar.

4. Masyarakat khususnya yang bekerja pada industri dapat menggunakan jaminan kesehatan berupa fasilitas rumah sakit yang dirujuk oleh perusahaan demi meringankan biaya pribadi.

\section{DAFTAR PUSTAKA}

[BPS] Badan Pusat Statistik. 2013. Kecamatan Caringin dalam Angka 2013. [internet]. [diunduh 2016 Desember 26]. Dapat diakses melalui: https://bogorkab.bps.go.id/new/website/ pdf_publikasi/Kecamatan-CaringinDalam-Angka-2013.pdf

[BPS] Badan Pusat Statistik. 2015. Indikator Kesejahteraan Rakyat 2015. Jakarta (ID): Badan Pusat Statistik. [internet]. [diunduh 2016 Juni 15]. Dapat diakses melalui: http://bps.go.id/index.php/publikasi/112 2

[BPS] Badan Pusat Statistik. 2016. Jumlah Penduduk Miskin Menurut Provinsi, 2013-2015. [internet]. [diunduh 2016 Mei 30]. Dapat diakses melalui: 
http://bps.go.id/linkTableDinamis/view/i $\mathrm{d} / 1119$

[BPS] Badan Pusat Statistik. 2016. Jumlah Penduduk Berumur 15 Tahun Ke Atas yang Bekerja Menurut Provinsi dan Lapangan Pekerjaan Utama, 1986-2016. [internet]. [diunduh 2017 Januari 24]. Dapat diakses melalui: http://bps.go.id/Subjek/view/id/6\#subjek ViewTab3|accordion-daftar-subjek1

[UU] Undang-Undang Nomor 3 Tahun 2014 tentang Perindustrian. [internet]. [diunduh 2016 Desember 26]. Dapat diakses melalui: http://www.kemenperin.go.id/download/ 5181/Undang-Undang-No-3-Tahun2014-Perindustrian

2015. Data Profil Desa Ciherang Pondok, Kecamatan Caringin, Kabupaten Bogor.

Gandi R. 2011. Pengaruh industrialisasi pedesaan terhadap taraf hidup masyarakat di RW 01 dan RW 09 Desa Benda, Kecamatan Cicurug, Kabupaten Sukabumi, Provinsi Jawa Barat. [skripsi]. Bogor (ID): Institut Pertanian Bogor. [internet]. [diunduh 2016 Maret 7]. Dapat diakses melalui:http://repository.ipb.ac.id/bitstre am/123456789/51851/1/i11rga.pdf

Purwanto. 2003. Perubahan pola pencaharian nafkah masyarakat petani di sekitar kawasan industri (Kasus di Desa Ngoro, Kabupaten Mojokerto, Jawa Timur). [tesis]. Bogor (ID): Insitut Pertanian Bogor.

Rahayu D. 2014. Dampak keberadaan agroindustri terhadap kesejahteraan masyarakat sekitar di Desa Sukamanah, Megamendung, Kabupaten Bogor. [skripsi]. Bogor (ID): Institut Pertanian Bogor. [internet]. [diunduh 2016 Maret 7]. Dapat diakses melalui: http://repository.ipb.ac.id/handle/123456 789/72093

Sarwono J. 2009. Statistik Itu Mudah: Panduan Lengkap untuk Belajar Komputasi Statistik Menggunakan SPSS 16. Yogyakarta (ID): ANDI.

Singarimbun M, Sofian E. 1989. Metode Penelitian Survai. Jakarta (ID): LP3ES.

Sulasmono BS. 1994. Respons masyarakat desa terhadap pembangunan industri besar (Kasus Desa Hardjosari, Kecamatan
Bawen, Kabupaten Semarang, Jawa Tengah. [tesis]. Bogor (ID): Institut Pertanian Bogor.

Tambunan M, Djaimi B. 2010. Rekonstruksi Strategi Industrialisasi. Yogyakarta (ID): Graha Ilmu.

Wijaya M. 2001. Prospek Industrialisasi Pedesaan. Surakarta (ID): Yayasan Pustaka Cakra. 